\title{
A Study on Awareness of Energy Drinks of Physical Education and Sports (Pes) Students
}

\author{
Eren Uluöz ${ }^{1}$, Ayșe Gencer ${ }^{2}$, Sibel Kamışl1 ${ }^{3}$ \\ ${ }^{1}$ School of Physical Education and Sports, Çukurova Universitesi, Adana, Turkey \\ ${ }^{2}$ Regents University, London, England \\ ${ }^{3}$ Sabancı Üniversitesi, İstanbul, Turkey \\ Correspondence: Eren Uluöz, School of Physical Education and Sports, Çukurova Universitesi, Adana, Turkey.
}

Received: October 31, 2018

doi:10.11114/jets.v6i12.3722
Online Published: November 26, 2018

URL: https://doi.org/10.11114/jets.v6i12.3722

\begin{abstract}
Energy drinks are often used by sedanter individuals as well as by individuals engaged in sports. The purpose of this study is to determine the energy drinks consumption habits of the students of PES. Total of 102 (Female:33/Male:69) from Çukurova University PES students were chosen as the participants since they were to be aware of the impact of energy drinks. Data utilizing descriptive and causal comparative research methods revealed that $42.2 \%$ of participants reported using energy drink while $57.8 \%$ did not. The energy consumption ratios of the users versus non-user compared in terms of socio-demographic variables such as "sex", "age", "socioeconomic status", "living place", "income situation", "place of birth" and "lifestyle" categories did not show any statistically significant differences $(p>0,05)$. In relation to the causes of consuming energy drinks, both consumers and non-consumers stated that energy drinks were for "being vigorous or energetic (34,9\%)", "keeping energy high while doing sports (32,6\%)" and "mixing with alcohol (16,3\%)". Total of $60,7 \%$ of all participants and $74,4 \%$ of those who regularly use energy drinkers reported that they do not know the harm of energy drinkers. Since energy drinks contain caffeine or other stimulants, consumption during intensive physical activity is not recommended. Therefore, consumption of energy drinks during intensive physical activity is not recommended. Consequently, although energy consumption in low quantities provides some temporary advantages for healthy people, it can trigger many health problems when examined from the general population standpoint. More consciousness-raising activities on energy consumption in particular in individuals with chronic systemic disorders and in special groups such as sportsmen may reduce unconscious consumption which can cause serious health problems.
\end{abstract}

Keywords: energy drinks, PES students, consumption habits

\section{Introduction}

In recent years, energy drink consumption has been increasing rapidly in our country as in the whole world. Although the composition of energy drinks, which provides mental alertness, increases durability and energy, reduces fatigue and improves performance in general, varies among firms, it has been reported to contain generally caffeine, guarana, glucuronolactone, taurine, ginseng, L-carnitine, sugar and vitamin B (Seifert ve ark., 2011; Bulut ve ark., 2014; Arpac1 ve Ersoy, 2011). When the general market share is examined, it is reported that energy drinks are sold regularly in approximately 140 countries, the USA is the fastest growing beverage market, and annual sales are expected to reach US \$ 9 billion in the last 3-5 years. It has been reported that adolescents between 12-18 and young people aged 19-25 constitute half of the energy drink market (Seifert et al., 2011). In Turkey, the consumption and popularity of energy drinks are increasing rapidly. The ingredients in the content of the energy content have been reported to have tolerable effects for healthy people at low doses, especially in individuals with systemic disorders, which can lead to serious complications that can result in sudden death if taken in an overdose. In Turkey, the consumption and popularity of energy drinks are increasing rapidly. The ingredients in the content of the energy drinks have been reported to have tolerable effects for healthy people at low doses, especially in individuals with systemic disorders, which can lead to serious complications that can result in sudden death if taken in an overdose. When the literature related to this subject is examined, the unconscious consumption accelerates the heartbeat or rhythm disorder, reflux, restlessness, anxiety, muscle spasms, speech disorder, diuresis (urine increase), digestive system disorders, dehydration, insomnia, headache, hallucination, it is associated with serious health problems such as addiction, high blood pressure, gastric ulcer, cardiac 
arrest and coma (Gunja and Brown, 2012; Petit et al. 2012; Scott, El-Hassan and Khan, 2011; Wolk et al. 2012). Energy drinks are frequently used by individuals who are engaged in sports as well as sedentary individuals. In terms of physical activity and sports activities, it can be considered that the biggest problem is sometimes the same as energy drinks and sports drinks due to ignorance or neglect. Sports drinks according to Turkish Food Codex Regulation; it is defined as products containing carbohydrates and electrolytes, formulated to provide rapid re-uptake of carbohydrates, liquids and electrolytes lost by sports. However, energy drinks is on the label of the products sold under the notification "Athletes are not drink during intense physical activity and should not be consumed in order after rehydration" There is in the form of extremely sharp and clear warning (Turkish Food Codex Energy Drinks Communiqué, 2017). One of the main differences that distinguish energy drinks from sports drinks is that they contain stimulants like caffeine. As is known, the use of unconscious and excessive caffeine may cause dehydration (excessive loss of fluid) or electrolyte imbalance, and a wide range of risks may occur in athletes ranging from simple muscle spasms to sudden death. For this reason, the energy drink labels have the following warnings. "It should not be mixed with alcohol or consumed together", Children, persons under the age of 18, elderly, people with diabetes, high blood pressure, pregnant women, people with metabolic diseases, persons with kidney failure are not recommended for people sensitive to caffeine", "It is not an athlete's drink, it should not be consumed during rehydration during and after intense physical activity", "It is not recommended to consume more than $500 \mathrm{ml}$ per day", it has been reported that there are warnings. (Ministry of Agriculture and Rural Affairs, 2006; Translated by Arpaci and Ersoy, 2011). It can be considered that it is important to determine the energy drink consumption habits of individuals who are in the sports environment and to shed light on the advanced studies in this subject due to the risks reported frequently in the literature about energy drinks. In this context, the aim of this study is to determine the energy consumption habits of PES students. In addition to this main purpose, some sub-problems were investigated in study such as using frequency, differences of using status between the sociodemographic categories of participants.

\section{Method}

Design: Descriptive and causal comparative research methods were used in the study. In this study, a descriptive and relational study type, causal comparison model was used. In the causal comparison model, it answers the question of what is present in the natural environment. In order to make a causal comparison, it was stated that there should be at least two groups exposed to the same effects (Cohen and Manion, 1994).

Participants: This study was carried out in Çukurova University and 102 (Women: 33, Male: 69) students who studied at Çukurova University Physical Education and Sports High School participated in the study.

Data collection tools: The questionnaire form, which is used as a data collection tool, was prepared by the researchers in the literature by using the questionnaire forms used in the previous studies. Before the main study, the questionnaire form was applied with a 10-day interval in a group of 20 similar to the same sample group. The consistency of the responses was checked by comparing the first and last questionnaire responses of the participants. In addition, the results of the second survey in the pilot study showed that the questions in the questionnaire were correctly understood and the opinions of the participants and a statistical expert about the general structure of the questionnaire were taken. In accordance with the suggestions, the survey questions were revised again.

Data collection process: The research was conducted in the classroom environment. After the questionnaires were distributed to the participants, explanations were made about the questionnaire. After informing the research, participants who did not want to participate in the research were excluded from the study. Voluntary participants were included in the study.

Statistics: The raw data obtained in the study are summarized with statistical methods such as mean, standard deviation, frequency, percentage etc. Chi-square test was used to determine the relationship between categorical variables. The significance level was accepted as p <0.05 in all analyses (Büyüköztürk, 2012). 


\section{Results}

The Energy Drink Using Rates of the participants included in the study are shown in Figure 1.

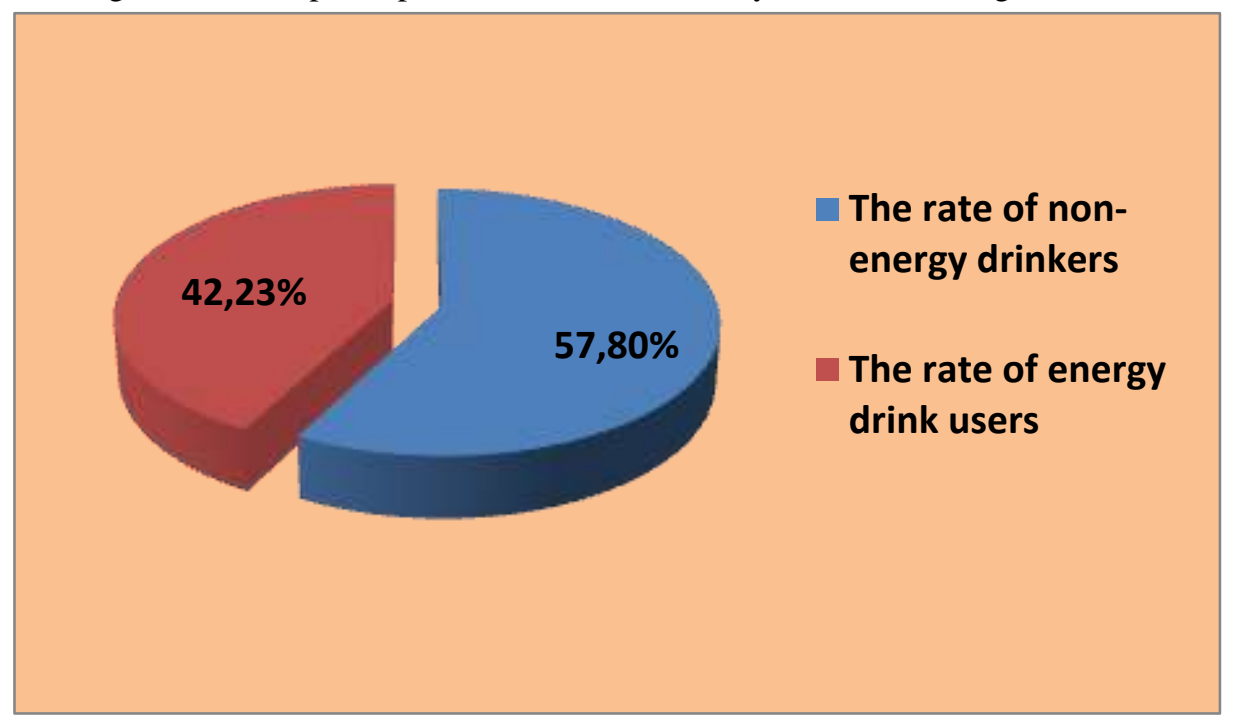

Figure 1. The Energy Drink Using Rates

In the study, it was found that $42.2 \%$ of the participants used energy drink when the data obtained with the data collection tools were examined. In contrast, $57.8 \%$ of the participants reported that they did not use energy drink. The comparison of the groups using and not using energy drink in terms of their gender is shown in Table 1.

Table 1. The result of the comparison of the groups using and not using energy drink in terms of their gender

\begin{tabular}{|c|c|c|c|c|c|c|c|c|}
\hline & \multirow{2}{*}{\multicolumn{2}{|c|}{$\begin{array}{l}\text { Using energy } \\
\text { drink }\end{array}$}} & \multicolumn{3}{|c|}{ Using energy drink } & \multicolumn{3}{|c|}{ Statistics } \\
\hline & & & Male & Female & Total & $X^{2}$ & $d f$ & $p$ \\
\hline \multirow{6}{*}{$\begin{array}{l}\text { Using energy drink X } \\
\text { Gender }\end{array}$} & & $\mathrm{n}$ & 33 & 10 & 43 & \multirow{6}{*}{2,81} & \multirow{6}{*}{1} & \multirow{6}{*}{0,09} \\
\hline & Yes & $\%$ & 32,4 & 9,8 & 42,2 & & & \\
\hline & \multirow[b]{2}{*}{ No } & $\mathrm{n}$ & 36 & 23 & 59 & & & \\
\hline & & $\%$ & 35,3 & 22,5 & 57,8 & & & \\
\hline & \multirow[b]{2}{*}{ Total } & $\mathrm{n}$ & 69 & 33 & 102 & & & \\
\hline & & $\%$ & 67,6 & 32,4 & 100,0 & & & \\
\hline
\end{tabular}

As seen in Table 1, the proportional differences between the use of energy drink and gender are not statistically significant $[\mathrm{X} 2(1)=2.81, \mathrm{p}=0.09]$. The comparison of the groups using and not using energy drink in terms of their place of birth is shown in Table 2 .

Table 2. The result of comparison of the groups using and not using the energy drink in terms of their place of birth

\begin{tabular}{|c|c|c|c|c|c|c|c|c|c|}
\hline & & & \multicolumn{4}{|c|}{ Birthplace } & \multicolumn{3}{|c|}{ Statistics } \\
\hline & \multicolumn{2}{|c|}{$\begin{array}{l}\text { Using energy } \\
\text { drink }\end{array}$} & Province & District & Village & Total & $X^{2}$ & $d f$ & $p$ \\
\hline & & $\mathrm{n}$ & 27 & 13 & 3 & 43 & \multirow[b]{6}{*}{2,97} & \multirow[b]{6}{*}{2} & \\
\hline & Yes & $\%$ & 26,5 & 12,7 & 2,9 & 42,2 & & & \\
\hline \multirow{4}{*}{$\begin{array}{c}\text { Using energy } \\
\text { drink X } \\
\text { Birthplace }\end{array}$} & & $\mathrm{n}$ & 34 & 14 & 11 & 59 & & & \\
\hline & No & $\%$ & 33,3 & 13,7 & $10,8 \%$ & 57,8 & & & \\
\hline & & $\mathrm{n}$ & 61 & 27 & 14 & 102 & & & \multirow[b]{2}{*}{0,22} \\
\hline & Total & $\%$ & 59,8 & 26,5 & $13,7 \%$ & 100,0 & & & \\
\hline
\end{tabular}


As seen in Table 2, there is no statistically significant difference between the participants' energy drink usage and birth rates, $[\mathrm{X} 2(2)=2.97, \mathrm{p}=0.22]$.

The comparison of the groups using and not using energy drink in terms of their age groups is shown in Table 3.

Table 3. The result of comparison of the groups using and not using the energy drink in terms of their age groups

\begin{tabular}{|c|c|c|c|c|c|c|c|c|c|c|}
\hline \multirow{8}{*}{$\begin{array}{l}\text { Using energy drink X } \\
\text { age groups }\end{array}$} & \multirow{2}{*}{\multicolumn{2}{|c|}{$\begin{array}{l}\text { Using energy } \\
\text { drink }\end{array}$}} & \multicolumn{5}{|c|}{ Age groups } & \multicolumn{3}{|c|}{ Statistics } \\
\hline & & & $17-19$ & $20-22$ & $23-25$ & $26+$ & Total & $X^{2}$ & $d f$ & $p$ \\
\hline & \multirow[t]{2}{*}{ Yes } & $\mathrm{n}$ & 11 & 21 & 7 & 4 & 43 & \multirow{6}{*}{3,89} & \multirow{6}{*}{3} & \multirow{6}{*}{0,27} \\
\hline & & $\%$ & 10,8 & 20,6 & 6,9 & 3,9 & 42,2 & & & \\
\hline & \multirow[t]{2}{*}{ No } & $\mathrm{n}$ & 24 & 20 & 12 & 3 & 59 & & & \\
\hline & & $\%$ & 23,5 & 19,6 & 11,8 & 2,9 & 57,8 & & & \\
\hline & \multirow[t]{2}{*}{ Total } & $\mathrm{n}$ & 35 & 41 & 19 & 7 & 102 & & & \\
\hline & & $\%$ & 34,3 & 40,2 & 18,6 & 6,9 & 100,0 & & & \\
\hline
\end{tabular}

As seen in Table 3, there is no statistically significant difference between the participants' energy drink usage and their age groups $\left[\mathrm{X}^{2}(3)=3,89, \mathrm{p}=0,27\right]$.

The comparison of the groups using and not using energy drink in terms of living space is shown in Table 4.

Table 4. The result of the comparison of the groups using and not using energy drink in terms of their living space

\begin{tabular}{|c|c|c|c|c|c|c|c|c|c|c|}
\hline \multirow{8}{*}{$\begin{array}{l}\text { Using } \\
\text { energy } \\
\text { drink X } \\
\text { Living } \\
\text { space }\end{array}$} & \multirow{2}{*}{\multicolumn{2}{|c|}{$\begin{array}{l}\text { Using energy } \\
\text { drink }\end{array}$}} & \multicolumn{5}{|c|}{ Living space } & \multicolumn{3}{|c|}{ Statistics } \\
\hline & & & \multirow{2}{*}{$\begin{array}{c}\text { Family } \\
31\end{array}$} & \multirow{2}{*}{$\begin{array}{c}\text { Alone } \\
4\end{array}$} & \multirow{2}{*}{$\begin{array}{c}\text { Dorm } \\
4 \\
\end{array}$} & \multirow{2}{*}{$\begin{array}{c}\text { Homemate } \\
4\end{array}$} & \multirow{2}{*}{$\begin{array}{c}\text { Total } \\
43\end{array}$} & \multirow[t]{2}{*}{$X^{2}$} & \multirow[t]{2}{*}{$d f$} & \multirow[t]{2}{*}{$p$} \\
\hline & Yes & $\mathrm{n}$ & & & & & & & & \\
\hline & & $\%$ & 30,4 & 3,9 & 3,9 & 3,9 & 42,2 & \multirow{5}{*}{0,55} & \multirow{5}{*}{3} & \multirow{5}{*}{0,90} \\
\hline & No & $\mathrm{n}$ & 39 & 6 & 8 & 6 & 59 & & & \\
\hline & & $\%$ & 38,2 & 5,9 & 7,8 & 5,9 & 57,8 & & & \\
\hline & Total & $\mathrm{n}$ & 70 & 10 & 12 & 10 & 102 & & & \\
\hline & & $\%$ & 68,6 & 9,8 & 11,8 & 9,8 & 100,0 & & & \\
\hline
\end{tabular}

As seen in Table 4, there is no statistically significant difference between the participants' energy drink usage and their living space $\left[\mathrm{X}^{2}(3)=0,55, \mathrm{p}=0,90\right]$.

The comparison of the groups using and not using energy drink in terms of their financial status is shown in Table 5.

Table 5. The result of the comparison of the groups using and not using energy drink in terms of their financial income

\begin{tabular}{|c|c|c|c|c|c|c|c|c|c|c|}
\hline & \multirow{2}{*}{\multicolumn{2}{|c|}{$\begin{array}{l}\text { Using energy } \\
\text { drink }\end{array}$}} & \multicolumn{5}{|c|}{ Financial income (Turkish Lira) } & \multicolumn{3}{|c|}{ Statistics } \\
\hline & & & $0-299$ & $300-599$ & $600-799$ & $800-1000$ & Total & $X^{2}$ & $d f$ & $p$ \\
\hline \multirow{6}{*}{$\begin{array}{c}\text { Using } \\
\text { energy } \\
\text { drink X } \\
\text { Financial } \\
\text { income }\end{array}$} & Yes & $\mathrm{n}$ & 17 & 12 & 9 & 5 & 43 & \multirow{6}{*}{3,71} & \multirow{6}{*}{3} & \multirow{6}{*}{0,29} \\
\hline & & $\%$ & 16,7 & 11,8 & 8,8 & 4,9 & 42,2 & & & \\
\hline & \multirow[t]{2}{*}{ No } & $\mathrm{n}$ & 31 & 13 & 13 & 2 & 59 & & & \\
\hline & & $\%$ & 30,4 & 12,7 & 12,7 & 2,0 & 57,8 & & & \\
\hline & \multirow[t]{2}{*}{ Total } & $\mathrm{n}$ & 4 & 25 & 22 & 7 & 102 & & & \\
\hline & & $\%$ & 47,1 & 24,5 & 21,6 & 6,9 & 100,0 & & & \\
\hline
\end{tabular}

As seen in Table 5, there is no statistically significant difference between the participants' energy drink usage and their financial status $\left[\mathrm{X}^{2}(3)=3,71, \mathrm{p}=0,29\right]$.

The comparison of the groups using and not using energy drink in terms of their socio-economic status is shown in Table 6. 
Table 6. The result of the comparison of the groups using and not using energy drink in terms of their socio-economic status

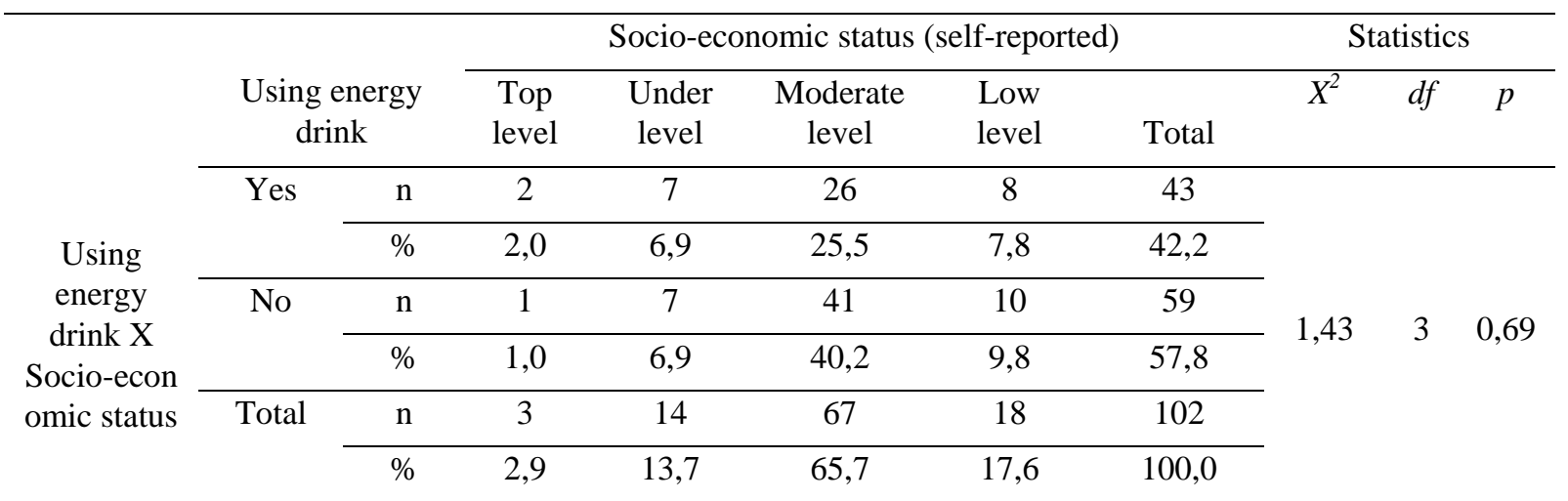

As seen in Table 6, there is no statistically significant difference between the participants' energy drink usage and their socio-economic status [X2 (3) $=1,43, \mathrm{p}=0,69]$.

The comparison of the groups using and not using energy drink in terms of their socio-economic status is shown in Table 7 .

Table 7. The result of the comparison of the groups using and not using energy drink in terms of their life style

\begin{tabular}{|c|c|c|c|c|c|c|c|c|c|c|}
\hline & \multirow{2}{*}{\multicolumn{2}{|c|}{$\begin{array}{c}\text { Using } \\
\text { energy } \\
\text { drink }\end{array}$}} & \multicolumn{5}{|c|}{ Life styles of participants } & \multicolumn{3}{|c|}{ Statistics } \\
\hline & & & $\begin{array}{l}\text { Living } \\
\text { regularly }\end{array}$ & $\begin{array}{l}\text { Living } \\
\text { flexible }\end{array}$ & $\begin{array}{c}\text { Living free } \\
\text { style }\end{array}$ & Other & Total & $X^{2}$ & $d f$ & $p$ \\
\hline & Yes & $\mathrm{n}$ & 7 & 15 & 17 & 4 & 43 & \multirow{6}{*}{7,02} & \multirow{6}{*}{3} & \multirow{6}{*}{0,07} \\
\hline \multirow{5}{*}{$\begin{array}{c}\text { Using } \\
\text { energy } \\
\text { drink X } \\
\text { Life style }\end{array}$} & & $\%$ & 6,9 & 14,7 & 16,7 & 3,9 & 42,2 & & & \\
\hline & \multirow[t]{2}{*}{ No } & $\mathrm{n}$ & 20 & 21 & 11 & 7 & 59 & & & \\
\hline & & $\%$ & 19,6 & 20,6 & 10,8 & 6,9 & 57,8 & & & \\
\hline & \multirow[t]{2}{*}{ Total } & $\mathrm{n}$ & 27 & 36 & 28 & 11 & 102 & & & \\
\hline & & $\%$ & 26,5 & 35,3 & 27,5 & 10,8 & 100,0 & & & \\
\hline
\end{tabular}

As seen in Table 7, there is no statistically significant difference between the participants' energy drink usage and their life style [X2 (3) = 7,02, $\mathrm{p}=0,07]$.

The ratio of reasons for using energy drinks is shown in Figure 2.

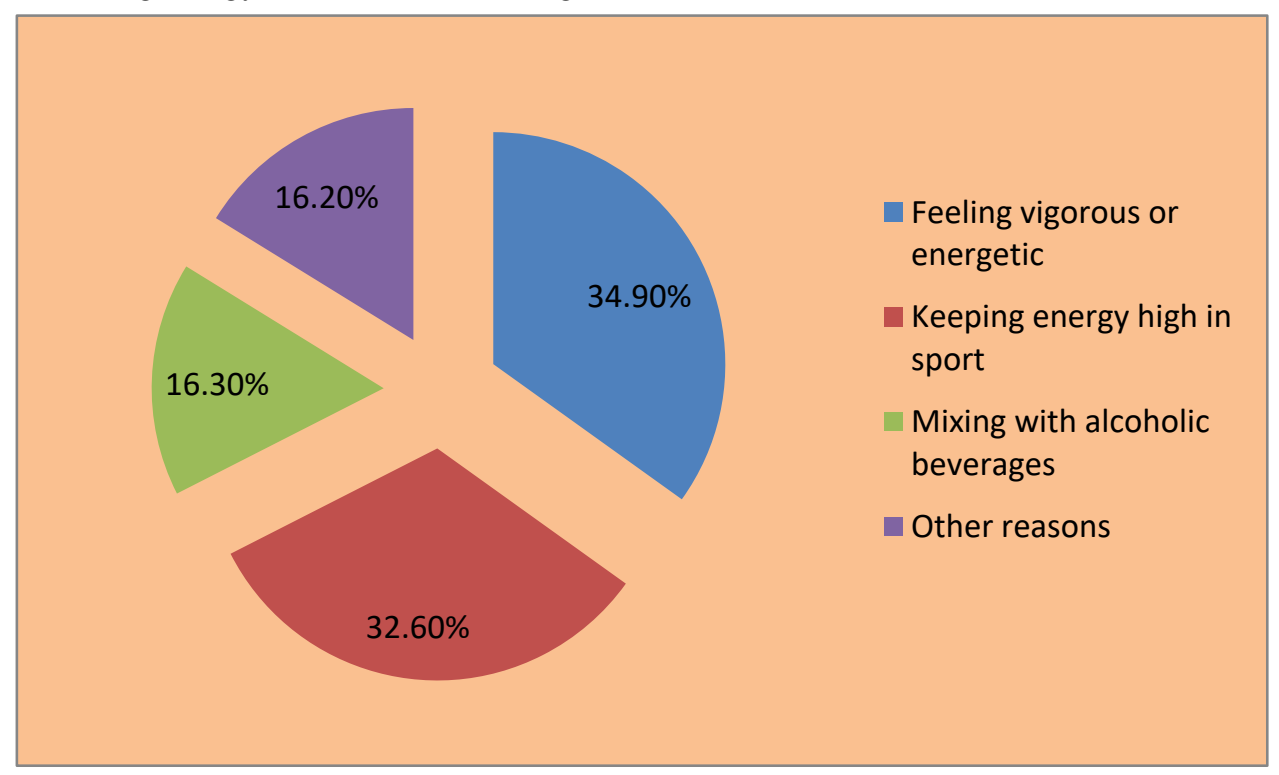

Figure 2. The ratio of reasons for using energy drinks 
As seen in Figure 2, when the participants' reasons for consuming energy drinks were examined, it was stated that "being vigorous or energetic (34.9\%)", "keeping energy high in sports (32.6\%)" and "mixing with alcoholic beverages $(16.3 \%)$ " are preferred reasons with the highest frequency.

The rates of awareness of all participants about the side effects of energy drinks are given Figure 3.

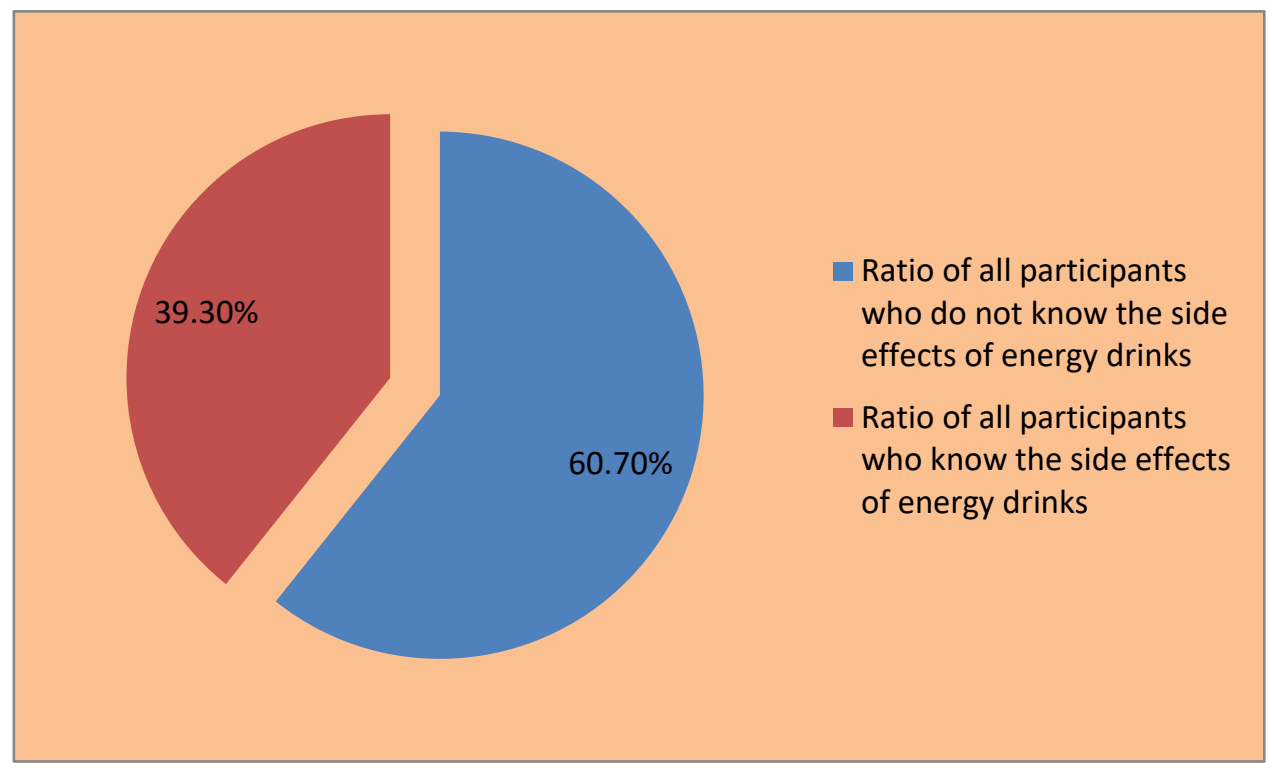

Figure 3. The rates of awareness of all participants about the side effects of energy drinks

As seen in Figure 3, the ratio of all participants who know the side effects of energy drinks was found $60,70 \%$. In contrast, the ratio of participants who do not know the side effects of energy drinks was found 39,30\%.

The rates of awareness of energy drink user participants about the side effects of energy drinks are given Figure 4.

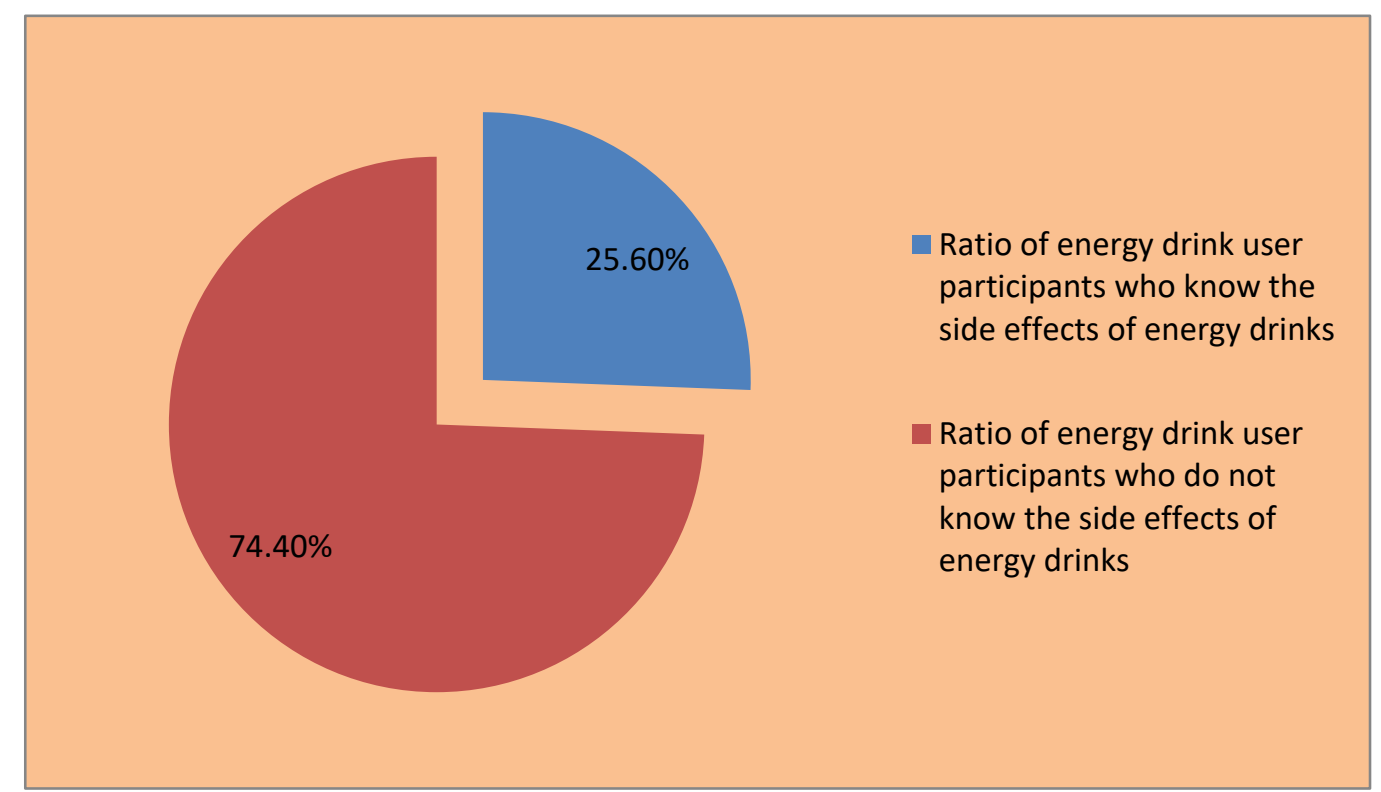

Figure 4. The rates of awareness of energy drink user participants about the side effects of energy drinks

As seen in Figure 4, the ratio of energy drink user participants who know the side effects of energy drinks was found $25,60 \%$. In contrast, the ratio of participants who do not know the side effects of energy drinks was found $74,40 \%$.

\section{Discussion}

In this study, $42.2 \%$ of the participants stated that they used energy drink. In contrast, $57.8 \%$ of the participants reported that they did not use energy drink. In a study by Bulut et al. (2014), it was reported that $46.5 \%$ of the participants used energy drinks at different frequencies. In another study conducted on university students in our country, the rate of 
energy drink use was reported to be $39.7 \%$ (Şen, Dere and Şen, 2015). The rates of use obtained in the study are similar to the literature. Nearly half of the participants stated that they used energy drinks in these studies. It can be thought that these high consumption rates are the result of the marketing strategies of the energy drink companies on the target population in these samples, which are intense and effective (highlighting the limited advantages of energy drinks and decorated with extreme sporting activities). In the study, it was found that energy drink consumption rates did not show a statistically significant difference between the groups in terms of gender, age, socioeconomic status, place of living, income, birth place and lifestyle categories ( $p>0.05$ ). Different researchers reported that socio-demographic variables were not related to consumption (Bulut et al., 2014; Şen, Dere and Şen, 2015; Sipahi, Sönmez and Aydın, 2015). This may be due to the aggressive and one-sided marketing strategies of energy drink companies. When the participants' reasons for consuming energy drinks were examined, it was stated that "being vigorous or energetic (34.9\%)", "keeping energy high in sports (32.6\%)" and "mixing with alcoholic beverages (16.3\%)" are preferred reasons with the highest frequency. It can be thought that the energy consumption habits of Physical Education students are related to the increasing energy needs in daily life without any relationship with sociodemographic variables. However, the official regulation on these beverages (Turkish Food Codex Regulation on Energy Drinks, 2017) necessitated the presence of a label on the health hazards of energy drinks in their packaging. For example, it is a legal obligation to have warning labels such as; "it is not an athlete's drink", "it should not be consumed for rehydration during and after intense physical activity", "it is not recommended to consume more than $500 \mathrm{ml}$ daily". Although there are such clear warnings about the harm to human health of energy drinks, the reasons for using the most preferred energy drink by the majority of the participants are reported as "keeping energy high during sports" and "mixing with alcohol". This unawareness and ignorance can be seen as a serious concern for public health. In this context, the most common reason for the energy consumption of PES students is "to keep their energy high (32.6\%)" and "to be energetic or vigorous (34.9\%)" while they are some of the significant negative findings in this study. Because in the PES course curriculum, students are given many courses related to human health such as nutrition, physiology, anatomy and athlete health. Another remarkable finding in this study is that $60.7 \%$ of all participants and $74.4 \%$ of those using regular energy drinks reported that they do not know the damages of the energy drink. In other studies conducted in similar samples in our country, it has been reported that consumers in similar age groups do not know about the harms of energy drinks. (Sipahi, Sönmez and Aydın, 2015; Şen, Dere and Şen, 2015). According to Sipahi et al. (2014), many young and sportsmen do not know the difference between energy drinks and sports drinks. In this respect, our study findings are similar to the literature.

In conclusion, although the consumption of low amounts of energy drinks provides some advantages in healthy individuals, it can be stated that the use of energy drinks in an excessive and unconscious manner can trigger many health problems when examined in terms of the general population. In this context, it can be considered that more awareness raising studies on energy drink consumption in special groups such as athletes and individuals with chronic systemic disorders and, may reduce unconscious consumption which may cause serious health problems. We think that, for awareness of students about the harms of energy drinks, the major differences between athletic beverages and energy drinks should be taught clearly in all courses related to human health such as physiology, sports health, sports nutrition, sports medicine, public health, preventive medicine and nursing schools.

\section{References}

Arpacı, N., \& Ersoy, G. (2011). Enerji içeceklerinin gücü nedir. Uluslararası İnsan Bilimleri Dergisi, 8(1), 809-822. https://www.j-humansciences.com/ojs/index.php/IJHS/article/viewFile/1469/725

Bulut, B., Beyhun, N. E., Topbaş, M., \& Can, G. (2014). Energy drink use in university students and associated factors. Journal of community health, 39(5), 1004-1011. https://doi.org/10.1007/s10900-014-9849-3

Büyüköztürk, Ş., Çakmak, E. K., Akgün, Ö. E., Karadeniz, Ş., \& Demirel, F. (2008). Bilimsel araştırma yöntemleri. Ankara: Pegem Akademi.

Cohen, L., Manion, L., \& Morrison, K. (1994). Educational research methodology. Athens: Metaixmio.

Gunja, N., \& Brown, J. A. (2012). Energy drinks: health risks and toxicity. Med J Aust, 196(1), 46-49. https://doi.org/10.5694/mja11.10838

Mroueh, A., Chaheen, M., Awada, S., Hajj, A., Salameh, P., Bawab, W., \& Rachidi, S. Risk Factors Related to the Consumption of Energy Drinks: Application in Lebanese School Students. Age, 16, 1-193.

Petit, A., Levy, F., Lejoyeux, M., Reynaud, M., \& Karila, L. (2012). Energy drinks: an unknown risk. La Revue du praticien, 62(5), 673-678. https://europepmc.org/abstract/med/22730801

Scott, M. J., El-Hassan, M., \& Khan, A. A. (2011). Unusual presentation of more common disease/injury: Myocardial infarction in a young adult following the consumption of a caffeinated energy drink. BMJ case reports, 2011. 
https://doi.org/10.1136/bcr.02.2011.3854

Seifert, S. M., Schaechter, J. L., Hershorin, E. R., \& Lipshultz, S. E. (2011). Health effects of energy drinks on children, adolescents, and young adults. Pediatrics, peds-2009. 511-528. https://doi.org/10.1542/peds.2009-3592

Şen, L., Dere, H. E., \& Şen, İ. K. (2015). Survey on Consumption Behaviour of Energy Drink Among University Students: Example of Afyon Kocatepe University. Turkish Journal of Agriculture-Food Science and Technology, 3(6), 394-401. https://doi.org/10.24925/turjaf.v3i6.394-401.264

Sipahi, H., Sönmez, İ., \& Aydın, A. (2014). Enerji İçecekleri ve İnsan Sağglığı Üzerindeki Etkileri. Turkiye Klinikleri Journal of Pharmacy Sciences, 3(1), 39-46.

http://www.turkiyeklinikleri.com/article/en-enerji-icecekleri-ve-insan-sagligi-uzerindeki-etkileri-69434.html

Türk Gıda Kodeksi Enerji İçecekleri Tebliği, 2017. http://www.resmigazete.gov.tr/eskiler/2017/06/20170930-23.htm

Wolk, B. J., Ganetsky, M., \& Babu, K. M. (2012). Toxicity of energy drinks. Current opinion in pediatrics, 24(2), 243-251. https://doi.org/10.1097/MOP.0b013e3283506827

\section{Copyrights}

Copyright for this article is retained by the author(s), with first publication rights granted to the journal.

This is an open-access article distributed under the terms and conditions of the Creative Commons Attribution license which permits unrestricted use, distribution, and reproduction in any medium, provided the original work is properly cited. 